\title{
NOTE
}

\section{Identification of Pseudomonas anguilliseptica isolated from several fish species in France}

\author{
Franck C. J. Berthe, Christian Michel, Jean-François Bernardet* \\ Unité de Virologie et Immunologie Moléculaires, Centre de Recherches INRA, F-78352 Jouy-en-Josas Cedex, France
}

\begin{abstract}
Since 1990, outbreaks of haemorrhagic septicemia, frequently associated with keratitis, have occurred on gilthead sea bream Sparus aurata, farmed along the French Mediterranean and Atlantic coasts. Several bacterial isolates obtained from diseased sea bream, sea bass Dicentrarchus labrax, and turbot Scophthalmus maximus showed phenotypic similarities with the Pseudomonas anguilliseptica Wakabayashi \& Egusa, 1972 type strain NCIMB 1949 The French isolates were compared with the type strain by determining levels of deoxyribonucleic acid (DNA) relatedness ( $\mathrm{S} 1$ nuclease method), guanine + cytosine content (thermal denaturation method), and by performing phenotypic tests. All of the isolates formed a tight genomic species with higher than $90 \%$ DNA relatedness to the type strain. This study demonstrates the phenotypic and genomic homogeneity of $P$. anguilliseptica and confirms that this bacterial species exhibits no host specificity. It thus represents a potential hazard for many farmed fish species and could cause serious economic losses
\end{abstract}

KEY WORDS: Pseudomonas anguilliseptica Sparus aurata. Dicentrarchus labrax . Scophthalmus maximus - Bacterial identification. DNA homology

Pseudomonas anguilliseptica was originally isolated by Wakabayashi \& Egusa (1972) from pond cultured Japanese eels Anguilla japonica suffering from 'sekiten-byo' (red spot disease). This bacterial disease caused mass mortalities during early summer 1971 in Japan. Since then, $p$. anguilliseptica has been recorded from European eels Anguilla anguilla in Taiwan (Kuo \& Kou 1978). In Europe, the pathogen was isolated in Scotland (Stewart et al. 1983) and later from Danish eel farms (Mellergaard \& Dalsgaard 1986). The disease was also reported from other fish species: black sea bream Acanthopagrus schlegeli (Nakajima et al. 1983), ayu Plecoglossus altivelis (Nakai et al. 1985), salmonid fish (Wiklund \& Bylund 1990) and more recently from wild Baltic herring Clupea harengus membras (Lönnström et al. 1994). The bacterium was first isolated in

\footnotetext{
- Addressee for correspondence
}

France by Michel and coworkers in 1992 from European eels reared in fresh water.

Since 1990, outbreaks of haemorrhagic septicemia, frequently associated with keratitis, have occurred during winter in farmed gilthead sea bream Sparus aurata along the French Mediterranean and Atlantic coasts. The disease was only observed at water temperatures below $16^{\circ} \mathrm{C}$ and the highest mortality occurred at water temperatures in the 9 to $13^{\circ} \mathrm{C}$ range. Abdominal distension causing a so-called 'belly-up' syndrome was often observed. Petechial haemorrhages were noticeable on the skin and the liver but the lesions observed in these outbreaks were less severe and extensive in comparison with the histopathology described in the Japanese (Miyazaki \& Egusa 1977) and European eel (Ellis et al. 1983). The bacterium was observed in blood smears and in some of the superficial dermis histological sections. Very recently, the disease was also noticed in farmed turbot Scophthalmus maximus and sea bass Dicentrarchus labrax in France.

Bacterial isolates obtained in pure culture from head-kidney and spleen appeared very similar in all of the outbreaks. Studies carried out to confirm that the isolates were Pseudomonas anguilliseptica are reported here.

Materials and methods. The bacterial isolates included in this study are listed in Table 1 along with their source. The type strain of the species Pseudomonas anguilliseptica NCIMB $1949^{\top}$ was also included in all of the tests as a reference strain.

The primary isolation of the bacteria was made on trypticase soy agar (TSA, bioMérieux, Charbonnièresles-Bains, France) at $22^{\circ} \mathrm{C}$. Gram staining was performed on tissues or blood smears and checked again on purified cultures. The general procedures described by Le Minor \& Véron (1989) and Carbonnelle \& Kouyoumdjian (1987) were used at $22^{\circ} \mathrm{C}$ to perform the basic tests, unless otherwise stated. 
Table 1. Pseudomonas anguilliseptica isolates included in this study

\begin{tabular}{|c|c|}
\hline Isolate" & Source \\
\hline NCIMB $1949^{\mathrm{T}}$ & $\begin{array}{l}\text { Blood, pond-cultured Japanese ee] } \\
\text { Anguilla japonica, Shizuoka Prefecture, } \\
\text { Japan, } 1971\end{array}$ \\
\hline JIP $14 / 91$ & $\begin{array}{l}\text { Head-kidney, gilthead sea bream } \\
\text { Sparus aurata, Mediterranean coast, } \\
\text { France, } 1991\end{array}$ \\
\hline JIP 24/91 & $\begin{array}{l}\text { Head-kidney, gilthead sea bream, } \\
\text { Mediterranean coast, France, } 1991\end{array}$ \\
\hline JIP 02/92-1 & $\begin{array}{l}\text { Head-kidney, gilthead sea bream, } \\
\text { Noirmoutiers Island, Atlantic coast, } \\
\text { France, } 1992\end{array}$ \\
\hline JIP 02/92-2 & $\begin{array}{l}\text { Same origin as strain } 02 / 92-1 \text {, but from } \\
\text { another fish }\end{array}$ \\
\hline JIP 02/92-3 & $\begin{array}{l}\text { Same origin as strains } 02 / 92-1 \text { and } 2 \text {, } \\
\text { but from another fish }\end{array}$ \\
\hline JIP 02/92-4 & $\begin{array}{l}\text { Same origin as strains } 02 / 92-1,2 \text { and } 3, \\
\text { but from another fish }\end{array}$ \\
\hline JIP 13/92-1 & $\begin{array}{l}\text { Head-kidney, gilthead sea bream, Ré } \\
\text { Island, Atlantic coast, France, } 1992\end{array}$ \\
\hline JIP $13 / 92-2$ & $\begin{array}{l}\text { Same origin as strain } 13 / 92-1 \text {, but from } \\
\text { another fish }\end{array}$ \\
\hline JLP 13/92-4 & $\begin{array}{l}\text { Same origin as strains } 13 / 92-1 \text { and } 2 \text {, } \\
\text { but from another fish }\end{array}$ \\
\hline LPAA 11066 & $\begin{array}{l}\text { Head-kidney, sea bass Dicentrarchus } \\
\text { labrax, Brittany, Atlantic coast, } \\
\text { France, } 1991\end{array}$ \\
\hline LPAA 11705 & $\begin{array}{l}\text { Turbot Scophthalmus maximus, } \\
\text { France, } 1994\end{array}$ \\
\hline LPAA 11706 & Turbot, France, 1994 \\
\hline LVDL 1291/94 & Spleen, turbot, Spain, 1994 \\
\hline \multicolumn{2}{|c|}{$\begin{array}{l}\text { "NCIMB, National Collection of Industrial and Marine } \\
\text { Bacteria, Aberdeen, Scotland, isolate provided by Prof. } \\
\text { H. Wakabayashi, Dept of Fisheries, Faculty of Agricul- } \\
\text { ture, University of Tokyo, Japan; JIP, collection of iso- } \\
\text { lates of the Unité de Virologie et Immunologie Molécu- } \\
\text { laires, Jouy-en-Josas, France; LPAA, Laboratoire de } \\
\text { Pathologie des Animaux. Aquatiques-Centre National } \\
\text { d'Etudes Vétérinaires et Alimentaires, Brest, France, } \\
\text { isolates provided by Dr M. Vigneulle; LVDL, Laboratoire } \\
\text { Vétérinaire DépartementaJ des Landes, Mont de } \\
\text { Marsan. France, isolate provided by Dr P. Nougayrède }\end{array}$} \\
\hline
\end{tabular}

Motility was investigated in wet mounts and hanging drops prepared from trypticase soy broth (TSB, bioMerieux) after incubation at $15^{\circ} \mathrm{C}$ according to the recommendations of Wakabayashi \& Egusa (1972). As growth of Pseudomonas anguilliseptica on marine Anacker \& Ordal agar (mAOA) seems to enhance motility (H. Wakabayashi pers. comm.), motility was also checked on bacteria grown on $\mathrm{mAOA}$ slants. AOA is composed of $0.05 \%$ tryptone, $0.05 \%$ yeast extract, $0.02 \%$ beef extract, and $0.02 \%$ sodium acetate (Anacker \& Ordal 1955); mAOA is prepared with 60\% seawater. The presence of flagella was checked by light microscopy after staining as described by Kodaka et al. (1982), and by transmission electron microscopy: cells suspended in saline were placed on Formvarcoated grids, fixed, negatively stained with $1 \%$ ammonium molybdate ( $\mathrm{pH} 4.5)$, and observed with a Philips EM12 transmission electron microscope operated at $80 \mathrm{kV}$

The following tests were performed on the 13 French isolates and on the type strain using commercially available media (Diagnostics Pasteur, Marnes-laCoquette, France): respiratory metabolismi production of cytochrome oxidase, catalase, indole (Kovac's reagent), and urease; $\mathrm{O} / \mathrm{F}$ test (modified Hugh \& Leifson's medium, MEVAG); fermentation of lactose and glucose and production of $\mathrm{H}_{2} \mathrm{~S}$ (Kliger's medium); reduction of nitrate $(1 \%$ nitrate broth); utilization of sodium citrate (Simmons' medium); tolerance to temperature $\left(5,30\right.$, and $\left.37^{\circ} \mathrm{C}\right)$ and salinity $(0,1$, and $3 \%$ $\mathrm{NaCl}$ ) in $1 \%$ peptone broth; $o$-nitrophenyl- $\beta$-D-galactopyranoside test; degradation of aesculin. Tweens 20 and 80 (according to Sierra 1957), DNA, casein (10\% skim milk TSA), and starch (0.5\% soluble starch TSA). Gelatin degradation was tested for by the film method (Le Minor \& Piechaud 1963): a strip of exposed photographic film was partially immersed in a thick bacterial suspension in saline, and the possible liquefaction of the thin black gelatin layer was observed after a $4 \mathrm{~d}$ incubation. Enzymatic profiles were determined in API ZYM galleries (bioMérieux) incubated overnight at $22^{\circ} \mathrm{C}$.

The Pseudomonas anguilliseptica type strain NCIMB $1949^{\top}$ was used to prepare a specific rabbit antiserum: saline suspensions containing increasing concentrations of formalin-killed bacterial cells were injected intravenously. Live cells of all of the isolates were tested in a rapid slide agglutination test against the non-diluted anti-Pseudomonas anguilliseptica serum. The agglutinin titer of the serum against homologous antigen was $1 / 128$.

Previously described methods were used to extract. purify, and shear unlabeled DNAs (Brenner et al. 1982). The procedure used for in vitro labeling of DNA with a tritium-labeled nucleotide $\left(\left[1^{\prime}, 2^{\prime}, 5^{\prime}-3 \mathrm{H}\right] \mathrm{dCTP}\right.$, Amersham, TRK625) has been published by Grimont et al. (1980), and modified by using a Megaprime kit (Megaprime DNA labeling system, Amersham, RPN1606). The method for hybridization experiments (S1 nuclease-DE81 method) has been described by Popoff et al. (1981).

The guanine-plus-cytosine content $(\mathrm{G}+\mathrm{C} \%)$ of the bacterial DNAs was determined by the thermal denaturation method and calculated using the equation of Marmur \& Doty (1962) as modified by De Ley (1970) 
Results and discussion. In pure culture, the isolates examined exhibited slow growth on TSA, producing tiny translucent non-pigmented colonies. The results of the phenotypic tests performed on the 13 French isolates are shown in Table 2, together with the characteristics of the type strain NCIMB $1949^{\mathrm{T}}$. From this limited range of classical phenotypical tests, the French isolates proved very similar Because of their rod shape, Gram-negative staining, polar flagellation, strict aerobic respiration, and production of cytochrome oxidase, these isolates were placed in the genus Pseudomonas. On the basis of morphological, physiological, and biochemical characteristics they were tentatively identified as $P$. anguilliseptica.

In the course of this study, motility was not observed in hanging drops and wet mounts prepared from cultures in TSB. However, it was possible to observe motility with some of the isolates grown on $\mathrm{MAOA}$ slants; flagella were observed by light microscopic

Table 2. Phenotypic characteristics of 13 French Pseudomonas anguilliseptica isolates and of the type strain NCIMB $1949^{\top}$

\begin{tabular}{|c|c|c|}
\hline & French isolates & NCIMB $1949^{\top}$ \\
\hline Gram stain & - & - \\
\hline Morphology & rod & rod \\
\hline Motility & + & + \\
\hline Cytochrome oxidase & + & + \\
\hline Catalase & + & + \\
\hline O/F test & - & - \\
\hline $\mathrm{H}_{2} \mathrm{~S}$ production & - & - \\
\hline Nitrate reduction & - & - \\
\hline Citrate Simmons & $+11 / 13^{\prime \prime}$ & + \\
\hline \multicolumn{3}{|l|}{ Fermentation of: } \\
\hline Glucose & - & - \\
\hline Lactose & - & - \\
\hline \multicolumn{3}{|l|}{ Growth at: } \\
\hline $5^{\circ} \mathrm{C}$ & + & + \\
\hline $30^{\circ} \mathrm{C}$ & + & + \\
\hline $37^{\circ} \mathrm{C}$ & - & - \\
\hline \multicolumn{3}{|l|}{ Growth in: } \\
\hline $0 \% \mathrm{NaCl}$ & + & + \\
\hline $1 \% \mathrm{NaCl}$ & + & + \\
\hline $3 \% \mathrm{NaCl}$ & + & + \\
\hline ONPG test & - & - \\
\hline Indole production & - & - \\
\hline Urease production & - & - \\
\hline \multicolumn{3}{|l|}{ Degradation of: } \\
\hline Casein & + & + \\
\hline DNA & + & + \\
\hline Aesculin & - & - \\
\hline Gelatin & - & - \\
\hline Starch & - & - \\
\hline Tween 20 & + & + \\
\hline Tween 80 & + & + \\
\hline
\end{tabular}

examination and by electron microscopy. Wakabayashi \& Egusa (1972) observed 2 types of cells by electron microscopy: one had a flagellum, while the second had no flagellum but a coiled flagellum-like structure within the envelope of the cell. From these observations, they concluded that Pseudomonas anguilliseptica exhibits a temperature-dependent expression of motility. The variability of motility with temperature was confirmed by the fact that motile cells increased in number when the culture, initially grown in a $25^{\circ} \mathrm{C}$ incubator, was moved to $15^{\circ} \mathrm{C}$. Variable motility was also reported by Shea et al. (1991) during a study of the gliding bacterium Deleya marina: a subpopulation of swimming cells appeared randomly and reversibly on subculture, exhibiting a surface-associated motility. Moreover, motility of Flavobacterium aquatile, the type species of a non-motile genus, was discussed by Holmes \& Owen (1979), highlighting the possible variability of this characteristic. Thus, in reporting a culture as non-motile, the test conditions must be precisely specified and the culture should be shown to lack flagella

Very few phenotypic discrepancies occurred among the isolates tested in the course of this study. The ability to grow in a $0 \% \mathrm{NaCl}$ peptone medium was exhibited by all of the isolates. This result was consistent with the data available for the type strain NCIMB $1949^{\mathrm{T}}$ from Wiklund \& Bylund (1990) and Lönnström et al. (1994). However, in the original description of the species (Wakabayashi \& Egusa 1972), no growth in $0 \%$ $\mathrm{NaCl}$ was recorded. Salt tolerance is usually determined using a nutrient broth supplemented with $0.1 \%$ $\mathrm{MgCl}_{2}$, and containing different $\mathrm{NaCl}$ concentrations (Wiklund \& Bylund 1990). The requirement for elements such as $\mathrm{Mg}^{++}, \mathrm{Ca}^{++}$or $\mathrm{K}^{+}$by many bacteria isolated from the marine environment has been reported (Bertrand \& Larsen 1989). Different concentrations of these elements in the media used for testing the ability to grow without $\mathrm{NaCl}$ could thus explain the discrepancies between data from different authors. However, Lönnstrom et al. (1994) showed that Pseudomonas anguilliseptica was capable of growing on Anacker \& Ordal's medium, which contains relatively low amounts of nutrients and which was not supplemented with $\mathrm{NaCl}$.

The French isolates and the type strain proved unable to hydrolyze gelatin with the film method. Most Pseudomonas anguilliseptica isolates from salmonid fish studied by Wiklund \& Bylund (1990) also failed to hydrolyze gelatin (method used unspecified). However, these authors as well as Wakabayashi \& Egusa (1972) found the type strain NCIMB $1949^{\top}$ to be positive for this test. Michel et al. (1992) observed that $P$. anguilliseptica strains initially capable of hydrolyzing gelatin readily lost this property after subculture. 
Table 3. API ZYM profiles of the 13 French isolates and of the Pseudomonas anguilliseptica type strain NCIMB $1949^{\mathrm{T}}$

\begin{tabular}{|c|c|c|}
\hline $\begin{array}{l}\text { Hydrolysis of the } \\
\text { following substrates }\end{array}$ & $\begin{array}{l}\text { NCIMB } \\
1949^{7}\end{array}$ & $\begin{array}{l}13 \text { French } \\
\text { isolates }\end{array}$ \\
\hline 2-Naphthyl-phosphate & $+^{d}$ & + \\
\hline 2-Naphthyl-butyrate & - & - \\
\hline 2-Naphthyl-caprylate & + & + \\
\hline 2-Naphthyl-myristate & + & - \\
\hline L-leucyl-2-naphthylamide & + & + \\
\hline L-valyl-2-naphthylamide & - & - \\
\hline L-cystyl-2-naphthylamide & - & - \\
\hline N-benzoyl-DL-arginine-2-naphthylamide & - & $-9 / 13^{b}$ \\
\hline N-glutaryl-phenylalanine-2-naphthylamide & - & - \\
\hline 2-Naphthyl-phosphate & + & + \\
\hline Naphthol-AS-BI-phosphate & + & + \\
\hline 6-Br-2-naphtyl- $\alpha$ D-galactopyranoside & - & - \\
\hline 2-Naphthyl- $3 \mathrm{D}$-galactopyranoside & - & - \\
\hline Naphthol-AS-BI- $\beta D$-glucuronide & - & - \\
\hline 2-Naphthyl- $\alpha \mathrm{D}$-glucopyranoside & - & - \\
\hline 6-Br-2-naphtyl- $\beta D$-glucopyranoside & - & - \\
\hline 1-Naphthyl-N-acetyl- $\beta D$-glucosaminide & - & - \\
\hline 6-Br-2-naphthyl- $\alpha \mathrm{D}$-mannopyranoside & - & - \\
\hline 2-Naphthyl- $\alpha \mathrm{L}$-fucopyranoside & - & - \\
\hline \multicolumn{3}{|c|}{$\begin{array}{l}\text { "API reaction scores } 0 \text { and } 1 \text { were considered negative; scores } 2 \\
\text { to } 5 \text { were considered positive } \\
\text { b } 9 \text { of the } 13 \text { isolates tested gave a negative result }\end{array}$} \\
\hline
\end{tabular}

available from Nakai et al. (1981), some Listonella anguillara (Vibrio anguillarum) and Aeromonas salmonicida strains were checked with this antiserum for possible cross reaction: no cross reaction was observed.

The base composition of the DNA of 7 representative isolates (JIP 02/92-1 to 4 and 13/92-1, 2 , and 4) and of the type strain NCIMB $1949^{\mathrm{T}}$ was in the 59 to 61 mol\% range as previously determined for the type strain and 2 Pseudomonas anguilliseptica isolates from eels using high pressure liquid chromatography (Michel et al. 1992). The lower $\mathrm{G}+\mathrm{C}$ content published by Stewart et al. (1983) has been discussed elsewhere (Michel et al. 1992).

The DNA-DNA hybridization studies showed that the 7 selected French isolates were more than $90 \%$ related to the type strain NCIMB $1949^{\mathrm{T}}$. With the method used in this study, 2 bacterial isolates are considered to belong to the same species when their DNA relatedness is at least $70 \%$. A more robust definition $(80 \%$ relatedness) was given by Grimont (1988); because our isolates complied with this definition, we felt no need for studying the thermal stability of the DNA hybrids.

Our phenotypic and genomic investigations

Another discrepancy should be pointed out in Table 2: DNAse production was found to be positive for the French isolates and the type strain, but was reported to be negative by Lönnström et al. (1994). As the method they used was not specified, it is possible that the discrepancy was due to the use of different methodological approaches.

The enzymatic profiles in API ZYM galleries are presented in Table 3. The profiles of the 13 French isolates were found to be very similar, except for the N-benzoyl-DL-arginine-2-naphthylamide test. The only discrepancy with the profile of the type strain occurred with 2-naphthyl-myristate: this substrate was hydrolyzed by the type strain but by none of the French isolates.

The slide agglutination reaction with the antiserum raised against the Pseudomonas anguilliseptica type strain was positive with all of the French isolates. An antiserum was also raised against a French $P$. anguilliseptica isolate from sea bream not included in this study (M. Vigneulle pers. comm.); the slide agglutination reaction was positive with all of the French isolates studied here, while the type strain did not agglutinate with this antiserum. As 2 different serotypes of $P$. anguilliseptica have been observed in Japan (Nakai et al. 1981), it is possible that the French isolate used for preparing the antiserum was of a different serotype than the type strain. Taking into account other data thus demonstrated that the French isolates belong to the species Pseudomonas anguilliseptica. This bacterial species appears very homogeneous as no characteristics capable of distinguishing the French strains from the type strain NCIMB 1949 T were found.

To investigate the pathogenicity of the isolates, some preliminary experimental infection tests were performed on several 10 -fish groups of $40 \mathrm{~g}$ sea bream (J.-F. Pépin pers. comm.). Bacterial suspensions at different concentrations $\left(1 \times 10^{7}\right.$ to $\left.4.8 \times 10^{7} \mathrm{CFU}_{\text {fish }}{ }^{-1}\right)$ in saline were inoculated by 3 routes: intraperitoneal injection, subcutaneous injection, and swabbing after scarification. All of the challenged fish died within a few days without exhibiting any external signs of disease and the bacterium was reisolated from all of the dead fish. In contrast, unchallenged controls all survived.

The Pseudomonas anguilliseptica infections are a cause for concern because the mortality is persistent and treatment is only partially effective. The bacterium was isolated from several farmed fish species and exhibits no host specificity. Since its first identification in Japan 22 yr ago, P. anguilliseptica has been found to occur in Scotland (Stewart et al. 1983), Finland (Wiklund \& Bylund 1990), Denmark (Mellergaard \& Dalsgaard 1986), and France (Michel et al. 1992). Large portions of the European coast seem to be affected; thus, this fish pathogen should be a growing source of 
concern for marine aquaculture in Europe. Moreover, because this widespread pathogen was recently isolated from wild fish (Lönnström et al. 1994), there is a need for further epizootiologic studies on $P$. anguilliseptica.

Acknowledgements. We are grateful to Dr M. Vigneulle (LPAA-CNEVA, Brest, France) for supplying the antiserum against the French isolate; we are indebted to Dr M. Vigneulle, Prof. H. Wakabayashi (Dept of Fisheries, Faculty of Agriculture, University of Tokyo, Japan), and Dr P. Nougayrède (LVD, Mont de Marsan, France) for kindly providing some of the strains used in this study, to R. Tytgat (Laboratorium voor Microbiologie, Universıteit Gent, Belgium) for determining the base composition of the DNAs, and to Dr $\mathrm{S}$. Chilmonczyk and B. Fléchon (INRA, Jouy-en-Josas, France) for kind help with the electron microscopy.

\section{LITERATURE CITED}

Anacker RL, Ordal EJ (1955) Study of bacteriophage infecting the myxobacterium Chondrococcus columnaris. I Bacteriol 70:738-741

Bertrand JC, Larsen H (1989) La 'bactérie marine': mythe ou réalité In: Bianchi $M$, Marty $D$, Bertrand JC, Caumette $P$, Gauthier M (eds) Micro-organismes dans les écosystèmes océaniques. Masson, Paris, p 3-25

Brenner DJ, MCWhorter AC, Leete Knutson JK, Steigerwalt AG (1982) Escherichia vulneris: a new species of Enterobacteriaceae associated with human wounds. J clin Microbiol 15:1133-1140

Carbonnelle B, Kouyoumdjian S (1987) Les techniques et les étapes de l'analyse. In: Carbonnelle B, Denis F, Marmonier A, Pinon G, Vargues R (eds) Bactériologie médicale. SIMEP, Paris, p 9-30

De Ley, J (1970) Reexamination of the association between melting point, buoyant density, and chemical base composition of deoxyribonucleic acid. J Bacteriol 101:738-754

Ellis AE, Dear G, Stewart, DJ (1983) Histopathology of 'sekiten-byo' caused by Pseudomonas anguilliseptica in the European eel, Anguilla anguilla L, in Scotland. J Fish Dis 6:77-79

Grimont PAD (1988) Use of DNA reassociation in bacterial classification. Can J Microbiol 34:541-545

Grimont PAD, Popoff MY, Grimont F, Coynault C, Lemelin M (1980) Reproducibility and correlation study of three deoxyribonucleic acid hybridization procedures. Curr Microbiol 4:325-330

Holmes B, Owen RJ (1979) Proposal that Flavobacterium breve be substituted as the type species of the genus in place of Flavobacterium aquatile and emended description of the genus Flavobacterium: status of the named species of Flavobacterium. Int J system Bacteriol 29:416-426

Kodaka H, Armfield AY, Lombard GL, Dowell VR (1982)

Responsible Subject Editor- T. Evelyn, Nanaimo, B.C., Canada
Practical procedure for demonstrating bacterial flagella $\mathrm{J}$ clin Microbiol 16:948-952

Kuo S-C, Kou G-H (1978) Pseudomonas angulliseptica isolated from red spot disease of pond-cultured eel. Anguilla japonica. Rep Inst Fish Biol, Min Econ Aff, Nat Taiwan Univ 3:19-23

Le Minor L, Piechaud M (196.3) Uno méthode rapide de recherche de la protéolyse de la gólatine. Ann's Inst Pasteur, Paris 105:792-794

Le Minor L, Véron M (1989) Bactériologie médicale Médecines-Sciences Flammarion, Paris

Lönnström L, Wiklund T, Bylund G (1994) Pseudomonas anguilliseptica isolated from Baltic herring Clupea harengus membras with eye lesions. Dis aquat Org 18:143-147

Marmur J, Doty P (1962) Determination of the base composition of deoxyribonucleic acid from its thermal denaturation temperature. J molec Biol 5:109-118

Mellergaard S, Dalsgaard I (1986) Håndbog i Ålesygdomme. Danm Fisk- og Havunders Rapp 293:33-34

Michel C, Bernardet J-F, Dinand D (1992) Phenotypic and genotypic studies of Pseudomonas anguilliseptica strains isolated from farmed European eels (Anguilla änguilla) in France. Fish Pathol 27:229-232

Miyazaki T, Egusa S (1977) Histopathological studies of red spot disease of the Japanese eel (Anguilla japonica) 1. Natural infection. Fish Pathol 12:39-49

Nakai T, Hanada H, Muroga K (1985) First :ecords of Pseudomonas anguilliseptica infection in cultured ayu, Plecoglossus altivelis. Fish Pathol 20:481-484

Nakai T, Muroga K, Wakabayashi H (1981) Serological properties of Pseudomonas anguilliseptica in agglutination Bull Jap Soc scient Fish 47:699-703

Nakajima K, Muroga K, Hancock REW (1983) Comparison of fatty acid, protein, and serological properties distinguishing outer membranes of Pseudomonas angulliseptica strains from those of fish pathogens and other pseudomonads. Int J system Bacteriol 33:1-8

Popoff MY, Coynault C, Kiredjian M, Lemelin M (1981) Polynucleotide sequence relatedness among motile Aeromonas species. Curr Microbiol 5:109-114

Shea C, Nunley JW, Smith-Somerville HE (1991) Variable expression of gliding and swimming motility in Deleya marina. Can J Microbiol 37:808-814

Sierra G (1957) A simple method for the detection of lipolytic activity of microorganisms and some observations of the influence of the contact between cells and fatty substrates. Antonie van Leeuwenhoek 23:15

Stewart DJ, Woldemariam K, Dear G, Mochaba FM (1983) An outbreak of 'sekiten-byo' among cultured European eels, Anguilla anguilla $\mathrm{L}$, in Scotland. J Fish Dis 6:75-76

Wakabayashi. H, Egusa S (1972) Characteristics of a Pseudomonas sp. from an epizootic of pond-cultured eels (Anguilla japonica). Bull Jap Soc scient Fish 38:577-587

Wiklund T, Bylund G (1990) Pseudomonas anguilliseptica as a pathogen of salmonid fish in Finland. Dis aquat Org 8:13-19

Manuscript first received: June 20,1994

Revised version accepted: October 25, 1994 